\title{
Ambroise Paré, surgery, and obstetrics
}

\author{
Matthieu Vinchon
}

Published online: 5 December 2008

(C) Springer-Verlag 2008

Ambroise Paré (1510-1590) is among the founding fathers of surgery and one of the most luminous figures in the dark period of the late sixteenth century in France (Fig. 1). Amid times torn by wars and religious intolerance, he maintained the ideals of humanism.

A self-taught man, he started learning surgery on the battlefields, as an aide to the count of Laval's private surgeon, then became a surgeon companion at the HôtelDieu in Paris, before being hired as master barber-surgeon for the duke of Montjean, colonel-general of the infantry. A surgical pioneer, he promoted arterial ligation two centuries before John Hunter, to whom this invention is widely credited. His work on firearm wounds attest of his practical skills acquired on the field and of his sense of observation [1]. His reputation spread after having cured several highranking noblemen, and he was appointed first royal surgeon in 1551. In the medical world of his times, he appeared as maverick, not knowing Latin and learning medicine from experience rather than in classical treaties. It required his royal patron's intervention for him to obtain his medical graduation in 1554, initiating the reunion of surgery and medicine which has prevailed to our time. He was unsuccessful however in his attempt to save King Henry II's life, after the latter had sustained a penetrating cerebral wound during a tournament.

M. Vinchon $(\bowtie)$

Pediatric Neurosurgery, Lille University Hospital,

59037 Lille Cedex, France

e-mail: m-vinchon@chru-lille.fr

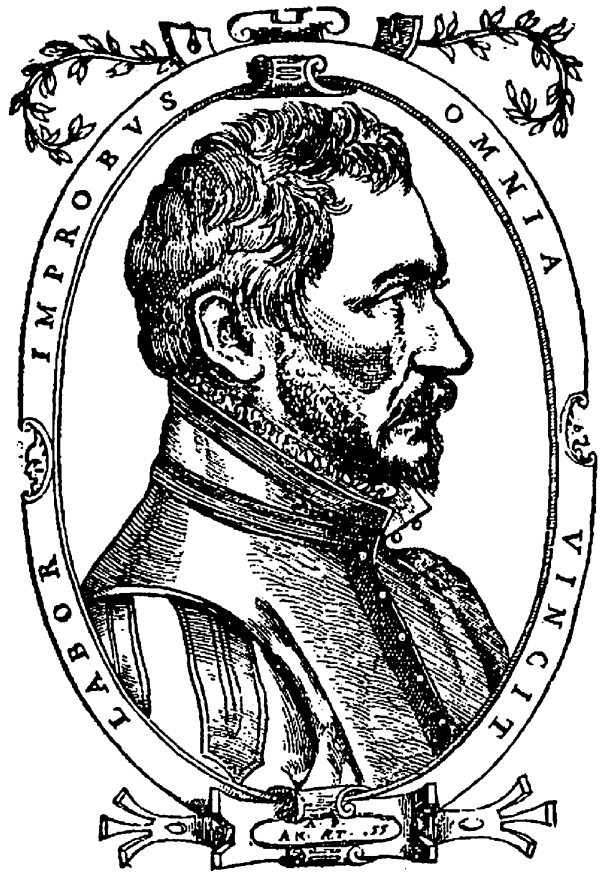

Fig. 1 Ambroise Paré

Although Ambroise Paré's role as a founder of surgery is well acknowledged, his role as a founder of obstetrics is less well known. Human reproduction, until then the domaine réservé of midwives and surrounded with ignorance and superstition, was brought by him into the fold with medicine and science. He founded schools 
for midwives, elaborated on the training of wet nurses, and his book, de la génération de l'homme [2] became the founding block of obstetrics. In this book are depicted several items of interest to pediatric neurosurgeons, such as cephalhematoma as a consequence of forceful labor, and prenatal hydrocephalus (clearly distinguished from macrocephaly) and conjoined twins as causes of dystocia.

His motto omnia vincit labor improbus (work overcomes everything), derived from Virgil's Georgics, likened medical research to peasants' labor, and still conveys a message to surgeons of our time.

\section{References}

1. Paré Ambroise: Méthode de traiter les plaies faites par les hacquebutes et autres bastons à feu, et celles qui sont faites par la poudre à canon. [Methods to treat wounds caused by arquebuses and other firearms, and those caused by gunpowder], Paris, L'Angelié, 1552 (accessible online http://gallica.bnf.fr/ark:/12148/ bpt6k53824x, last visited August 17th, 2008)

2. Paré Ambroise: de la génération de l'homme \& manière d'extraire les enfants hors du ventre de leur mère. [On man's generation, and how to extract children out of their mother's womb], Wechel, Paris 1573 (accessible online http:/gallica.bnf.fr/ark:/12148/bpt6k53958h, last visited August 17th, 2008) 